\title{
Communicating COVID-19 Uncertainty: Lessons from the Past
}

\section{Chrysoula Kapartziani}

Department of Law, National and Kapodistrian University of Athens, Athens, Greece

\section{Email address:}

xkapartziani@yahoo.gr

\section{To cite this article:}

Chrysoula Kapartziani. Communicating COVID-19 Uncertainty: Lessons from the Past. International Journal of Literature and Arts. Vol. 9, No. 2, 2021, pp. 94-100. doi: 10.11648/j.ijla.20210902.16

Received: December 15, 2020; Accepted: April 1, 2021; Published: April 26, 2021

\begin{abstract}
This article examines the global response to the Covid-19 pandemic in the era of the risk society. It employs literature-based analysis and study of legal sources. The first part of the article presents the crucial role of communicating information during a pandemic and the role of WHO in the area of infectious diseases. Confidence, public trust, and public involvement are according to Urlich Beck critical for the acceptance of risk related policies. This article, through the paradigm of a pandemic of the past, (the case of the bubonic plague in Ionian islands), argues how crucial is the communication of the uncertainties, the involvement of the public and the information networks. Furthermore, it supports that during the covid-19 crisis, health risk communication and management of the crisis were not sufficient. Some of the reasons were: the unclearance of the message transmitted, limited public and community participation in the decision making process and in shaping the health policy, crisis of public confidence, inadequacy of implemented policies, e.t.c. It concludes that collective and just solution, harmonized global action, access to information, international solidarity, and the involvement of the locals are of paramount importance.
\end{abstract}

Keywords: Pandemic, Collective Responsibility, Public Participation, WHO, Risk-society, Information, Corona Virus, Global Politics

\section{Introduction}

Numerous plagues and diseases have erupted across the globe. The really serious difference between then and now pandemics, is the ability of a disease to move between countries at an unprecedented rate by air travel. Major cities are globally all joined within a one-day journey. The shaping of the global era went hand in hand with the increase of mobility via air traffic. National borders provide no barriers to the transmission of communicable diseases [1]. As WHO states "The airplane is another hallmark of modern times. Air travel has become commonplace and fast. The result is increased potential for rapid dispersion of infectious diseases to new environments. Other factors of the modern age that have increased the threat from communicable diseases include changes in land use and agriculture, and increased encroachment of people on forest and woodlands areas" [2]. Air traffic and high mobility can spread epidemic diseases at rates faster than they can be identified, especially since incubation periods before symptoms emerge, may often last many days. Air travel society is our new global society. Air traffic connects the new world, our world. In our new globalized area without airplanes, we are like Becketian stage figures, body fragments, living torsos, whose worlds and lives are out of joint [3].

Furthermore, in our global world, internet made information accessed easily by anyone to any part of the world -local information became global and vice versa. The scale of the transmitted data and information became enormous. One would assume that the spreading of the information in this post-modern context, would manage to detect in time the spreading of a new virus. But, is or was indeed this the truth?

Most of us first informed about the novel corona virus in late December 2019. The WHO's country office in China was notified on 31 December 2019. A causal disease agent was reported to WHO on 7 January by the National Health Commission of China [4]. On January $30^{\text {th }} 2020$, the International Health Regulations Emergency Committee convened by the WHO Director-General decided to declare a 
"public health emergency of international concern" [5].

On January $6^{\text {th }} 2020$ the New York Times published an article named: China Grapples with mystery pneumonia-like illness [6], the first of any Times reporting on the topic. In one paragraph, the piece quotes an expert who was frustrated by the lack of access to information from Chinese scientists [7].

Only at the start of January, epidemiologists began to receive reports from public health departments in China, which included rudimentary information about the number of new infections, hospitalizations and deaths. Newsrooms covering the pandemic were similarly chaotic. "There were all sorts of rumors and unconfirmed information flooding in every day. The easiest the access was the more difficult the assessment of the information became" [6].

On the other hand WHO's mechanisms and networks proved unable to track down the root cause or true source of the epidemic. One of the pivotal aims of WHO is to monitor the health situation and address health trends. The intergovernmental networks of monitoring did not work. Why aren't our modern methods dramatically better than methods from centuries past?

The constitution of WHO indicates that, nations are willing to cooperate in a broad range of health-related policy matters. WHO's structures are complex, with three levels of organization at an international level, which are directly related to the governmental networks of any state member. But what if the governmental networks do not function properly? What if the governments are not able to supply the necessary information? WHO is aware of the fact that it cannot function as an independent actor in the international system [8]. How well can WHO function in this international environment in relation to the warning of the pandemics?

Our interconnected information "overloaded" -world was not able to protect us nor to warn us in time for the disaster to come. Why that happened and what if anything can we learn from the past?

\section{Communicating Information During a Pandemic}

\subsection{The New Risk Society}

In the era of globalization and modernization, during the past two centuries, the notions of progress, comfort and rationality coexisted with deregulation, dismantling of the welfare state, shrinkage of public health sector, explosion of inequalities etc. Simultaneously a prolonged and sustained period of societal dissection and breakdown has made long distance relationships, living far and detached from one's family and customs for excessively long periods, working remotely, etc., characterize and indeed constitute features of today's' world, global domestic politics and international governance. In this process no attested knowledge could stand by on its own, risks of new technologies have multiplied, the world filled with uncertainties and the public's trust in institutions, national governments and governance, including organizations such as the WHO, has been abandoned long ago and along the wayside. The new risk society is full of invisible threats, chaotic and unforeseeable crises, such as the COVID-19 pandemic.

Even if advances in twentieth century technology revolutionized the communication of information, communicating disease information during such events is a very difficult task. Taking for example the persistence in numbers (such us numbers of infections, deaths, etc,) can be deceitful because it suggests scientific knowledge, where there is lack of evidence, and because it creates the sense of a major threat obscuring the differential nature of risk [9]. Transparency and accuracy of the information is of outmost importance in order to establish public trust [10]. However trust determination [11] theory supports, that when people are stressed and in a crisis event, they usually do not trust [12] authority. Consequently trust [13] ought to be established in advance of a crisis event, such as a pandemic. Proactive community [14] outreach and involvement is one of the most effective means of achieving this target.

Taking under consideration that infectious disease outbreaks are highly charged political and social events, [15] health risk communicators have to draw insights from sociological and cultural studies of risk [16]. Communication of risk can borrow insights from the work of Ulrich Beck and Covello. According to Beck, in a global society, the distribution of risks is never equitable but follows the unequal distribution of power. There is a great deal of controversy in the distribution of risks between expert views on risk and the views of citizens. Additionally, in times of crisis more and more matters arise of economic and political nature that require political decisions, such as travel restrictions, labor law, etc. All these issues create controversy. What seems as a simple health issue is a far more complex issue, that demands new solutions, new tools and ideas.

Crisis communication messages are based on what is known and not known about a current state of condition. As Covello argues, public health officials need to insist on their uncertainty. They need to make uncertainty the message, not the preamble to the message [17]. Beck theorizes that in times of uncertainty, because the science presently is immediately connected with the taking of decisions, participating in the political management of risk, citizens ought to have access to the scientific knowledge and participation in the taking of decisions. Through the dialogue and consultation, new forms of political action become apparent, as well as legalization of decisions of political authority. Covello \& Sandman also remark that the principle of involving the public in matters of risk, whether it is risk assessment, decision making etc, is crucial to risk/crisis communication [18]. In the past, governments ignored the public in matter of risks and crisis. They were aiming to protect the public rather than involve it [18].

\subsection{The Right to Information During a Pandemic}

The right to information and ensuring public access to information is a necessary response to every pandemic. The 
right to information is critical for building trust between people, governments, intergovernmental Organizations. The right to access to information is fundamental as declared in Article 19 of the Universal Declaration of Human Rights [19] and Article 19 of the International Covenant on Civil and Political Rights [20]. Additionally article 12 of the International Covenant on Economic, Social and Cultural Rights correlates the right of everyone to physical and mental health with the access to information by the community. [21] The Aarhus Convention, also requires that "in the event of any imminent threat to human health or the environment public bodies make public all information which could enable the public to take measures to prevent or mitigate harm \{...\}immediately and without delay to members of the public who may be affected" [22]. Last but not least the European Court of Human Rights judges that in cases of Environmental pollution states have a positive obligation towards citizens to collect and make information [23] available on health hazards.

UN Secretary General stressed that necessity and said "Authorities need to be open and transparent in their decision making and willing to listen to and respond to criticism"[24]. At the same line the Council of Europe stated, "Official Communications cannot be the only information channel about the pandemic. This would lead to censorship and suppression of legitimate concerns. Journalists media medical professionals, civil society activists and public at large must be able to criticize the authorities and scrutinize their response to the crisis" [25]. Reliable, accurate and accessible information is needed. WHO also states that "People have the right to be informed about and understand the health risks that they and their love ones face. They also have the right to actively participate in the response process [26].

Instead national governments responded, and media in turn, - in many cases- with misinformation, lack of coherence, undertaking hastily erroneous, inadequate measures which lead to public confusion, fear and lack of trust and understanding etc. Furthermore, there was no public discussion [27] about the consequences [28] of such measures. The idea to treat the virus as a global threat that would uniformly impact all people- even if global risks are not equitably distributed,- involved understanding ourselves as a universal nation confronting a threat that required everyone's sacrifice. Given that public participation process at most work on a nation-state level, the classic slogan of Greenpeace "think globally, act locally," applies in our case.

\subsection{The Role of WHO in the Area of Infectious Diseases}

WHO is the body of the United Nations (UN) responsible for directing and coordinating health. WHO is responsible for the implementation of International Health Regulations: surveillance, infection prevention and control, management of travel and trade and implementation of measures to maintain essential health services. As such, WHO has come to play a vital role as an actor in the field of international public health policy.
WHO's Outbreak Communications guidelines is one of the two main sources of guidelines and practices for communicating during pandemics and infectious diseases outbreaks [28].

In order to understand how WHO functions when dealing with the area of infectious diseases it is first necessary to understand something of the history, functions and structures of WHO, which are interrelated. The constitution of WHO indicates that, by the middle of the 20th century nations were willing to cooperate in a broad range of health-related policy matters. Chapter II, Article 2 of WHO's constitution lists the twenty-two functions of WHO [8]. Additionally structures of WHO are complex. WHO has three levels of organization at an international level, the World Health Assembly (WHA), comprising representatives of every WHO member state, the Executive board, which comprises members elected by the WHA and the Secretariat, comprised of WHO's DirectorGeneral and technical and administrative staff. The constitution also specifies provisions to create regional organizations and "committees considered desirable to serve any purpose within the competence of the organization" [8]. WHO is a fundamental actor of the international system [2] and has a neutral status and near universal membership. However, it becomes apparent, that WHO is closely connected to official member states and cannot function as an independent actor in the international system.

One of WHO's major functions, in the area of infectious diseases, is surveillance, prevention and control. At an international level it publishes recommendations on how to mitigate the risk and how to prevent, manage and treat many of the complications that can arise during this period. WHO has the mandate to lead and coordinate global surveillance. WHO's Surveillance systems must detect new communicable diseases as well as recognize and track diseases that currently are, or have the potential to become, of major public health importance [7]. This effective public health surveillance is critical for the early detection and prevention of epidemics. WHO also maintains international collaborating networks like the WHO Network of Collaborating centers for Influenza Surveillance which monitors strains of influenza.

In addition, WHO ensures international coordination of epidemic response, particularly for diseases of international public health importance or when countries lack the capacity to respond to an epidemic themselves. Responses can vary from investigating the cause of an epidemic, to verifying and disseminating information, and to providing needed equipment and laboratory supplies [29]. One of the main goals of communicable disease surveillance is the reporting and confirmation of cases seen in health facilities.

WHO governing body papers, highlight the gaps and needs in the broad area of reporting disease, gathering data, risk communication and community engagement [2]: «Countries are hesitant to report diseases covered by the International Health Regulations, in part for fear of economic consequences, and its effects on tourism and trade. In addition, for many diseases there is gross underreporting, under diagnosis, and delayed reporting. The quality of 
reporting varies considerably from country to country. Finally, international data are not completely comparable as reporting systems, case definitions, and the quality and availability of laboratory facilities vary from country to country» $[30]$.

Furthermore, it is important to show the ways in which WHO functions in relation to pandemics. In the Eleventh General Programme of Work 2006-2015, WHO defines itself largely as an agency for providing leadership in the area of international public health and international public health policy.

Did WHO responded to its role in the ongoing situation? Many believe that WHO acted with delay [31] in decreeing and communicating the seriousness of this virus as a global pandemic and has utterly failed in it's role to act quickly, decisively and effectively; Moreover, some believe that it allayed and communicated contradictory messages especially at the beginning of this crisis in February and March [32].

WHO's role is not only to warn and alert the public [33] to the very real danger and risks of COVID-19 as well as to the seriousness of this but also to reassure and calm the human population across the globe and assert and promote all the work it is doing in the field of surveillance, infection prevention and control. The WHO should make its major and clear aim to seek to calm and instill confidence into global society, into humanity, and explain the uncertainties to the public. The clearance of the message being communicated by WHO, governments and the media, thereby, is of outmost importance for the building of confidence by the public in international bodies and organizations etc. The message of uncertainty is better than a confused message.

Assessing the effectiveness of WHO in the pandemic is a quite complex issue [34]. Why the acquiring of accurate data in relation to COVID-19 was so difficult, though the acquisition of data is improving? Is there a dysfunction in the reporting and surveillance system of the WHO organization and what can be done for it? It is apparent from the WHO body papers that were aware of the flaws in its function, what they did to overcome these obstacles?

\section{Lessons from the Past}

During the 17th and 18th centuries, the Greek Ionian islands were under Venetian rule and occupation. Consequently they had political and institutional differences from the rest of Greece that was still under the Ottoman occupation. During this same period, the epidemic of the bubonic plague, also known as the black death, was dominant in Europe [35]. These Ionian Islands are ideal for research because of their crucial -globalized for that time, location. They were a getaway to and from Ottoman Empire and at the same time a frontier of Venice to the East [36]. Venice organized their defense against the plague from the time of the Black Death [37].

The Venetian State was a pioneer in organization of public health services conceived in the late Middle Ages, established regulations and practices both inside the city of
Venice and in its conquests. These regulations and practices included laws for plague control, identical institutions and infrastructures, quarantine, self-isolation, lazarettos, health board offices, interrogation system and cordoni di sanità, which on the Ionian Islands were coastal and local garrisons that controlled access to Venetian territories [38]. The lazarettos (quarantine station for maritime travelers) were established in Kerkyra (Corfu) and Zakynthos (Zante) in 1588 and in Kefalonia and Lefkada at the beginning of the 18 th century, while health board officers in Corfu and Zante were initially elected around 1545. The Venetian health policy was reformed in the 18th century. The new policy included the creation and implementation of a common identical health legal framework for all the islands.

Amongst the measures taken by the Venetian administration to combat the plague on the Ionian Islands were, the implementation of an information network that was pivotal and managed to decrease the epidemic's spread. In contrast, neighboring coasts of Greece, which were under Ottoman rule, were plague-ridden areas, during the same period of time.

It is worth mentioning that this information network was established at a time were the scientific basis of plague was still unknown [39]. The Venetian administration organized a network of communication of the information both local and metropolitan. There were Local sanitary authorities (health board offices) to every island that were in continuous communication with the Venice metropolitan authorities and at the same time with Venetian delegates in great mercantile spots in both East and West (i.e., Constantinople, modern day Istanbul, Thessaloniki, Alexandria etc) [37]. Ships departing from these ports were usually following trade routes towards the Ionian islands. The central sanitary authority (Ufficio di Sanità) minister was responsible to provide on time information and to warn all parties for suspected ships.

Information and latest news about the plague were at the epicenter of the responsibilities of local authorities, local health officials and venetian representatives and delegates. The locals were also involved in this network (local factions known as cittadini). There was a two way communication system. News were transmitted to Venice both by countries which confronted the plague via the implementation of certain measures, and from the Ottoman East, (that were of muslim tradition during that time made it difficult for human intervention and for effective isolation of suspected cases) [37]. All this correspondence which in some cases had as exclusive scope the pandemic, was collected and studied carefully in central Venice. Consequently, Venice leveraged the information and with the collaboration of local authorities and local health boards, undertook the necessary preventive measures. The detailed and in-depth account of the events and the tracking of population movements were of great importance to this correspondence.

A typical example [39] of how detailed this information was, is that retrieved from the year 1731. The plague had swept over the Greek city of Ioannina that was under the Ottoman rule. At this time the Venetian chief officer of the 
Sanitary authorities of the Ionian Islands communicated to the local health officer of the island of Lefkada, information about the movement of four families from the area of Ioannina to a village that was only two miles away from the island of Lefkada. (The island of Lefkada is united with the Greek mainland through a sliver of dry land). Even the slightest information ought to be transmitted! A system of inspections through garrisons along the coasts helped the Venetians to implement the preventive measures and control all local movements in plague-infested areas, which were immediately isolated.

In case that the mail-correspondence between local officers was delayed, certain officers were obliged to travel to suspected geographical areas, collect the necessary information and convey them to Venice and from there, back to the island. A tool that was used by the Venice authorities, for the collection of information was that of the interrogation of the merchant ship crew and of the captain, via a semistandardized questionnaire [40], as well as the interviewing of local people.

\section{Conclusion}

Venice was a trading centre, Ionian Islands where trade routes and both of these although coexisting, were especially vulnerable. A transnational system of Mediterranean lazzaretti [29], was established by Venice in order to allow and protect commerce and guarantee the continuation of socio-economic activity \& life. The creation and continuous functioning of Lazzaretti, beside the difficulties, was the only way to protect everyone's health and allow the economy to continue unaffected. Lazzaretti were the places where, travellers, merchants, sailors and goods coming from suspected places were quarantined before entering the islands, cities and crossing borders. Most of the Greek islands had their own lazarreti where strict rules on isolation and segregation were imposed. The functioning of lazzaretti involved local community. The guardians who had to ensure that the prescribed distances were kept when interacting with staff or non-quarantined people usually were local people. Food and supplies came from the local economy, etc.

Above all was the undertaking of preventive measures for the protection of public health that were directly correlated with the information available. The final goal was for all these measures to act as protective shield for Venice. In order to protect Venice the responsibility of plague control were transferred from Venice to peripheral areas. The waning of plague epidemics during the 18th century may be attributed to preventive measures taken by the Venetian government.

We conclude that even in the absence of scientific knowledge, close observation, information interchange, public involvement, social and political measures, consistency in the message communicated about the preventive measures, can effectively restrain infectious outbreaks to the point of disappearance and instill confidence into public society. What the case study, provides is evidence that there has been competent and professional risk communication and management from the Venetian side. Even if there was no community participation in the decision making, the clearance of the message about the uncertain outcome of the plague, made everyone more responsible towards the invisible threat. After all, acceptance of riskmitigating measures depends on the perceived trustworthiness and legitimation of risk communication. Even if there is a high degree of uncertainty of information, communicating that uncertainty is important.

How can we organize a defense when in most cases we don't even know our enemy? How can we re-weave edges and find new footing? How can we feel safe and protected in a globalized society? During a pandemic, knowledge is as critical as medicine. Modern knowledge depends on trusting long chains of experts, and every one of them knows only a small fragment of the story. The knowledge of the uncertainties is crucial to be communicated to the public. It is now widely recognized that risk communication is one of the first public health interventions in outbreaks and can be rolled out even when very little is known about the outbreak [41]. At the end of the day people are developing their own understanding about the virus. Todo so, access to information and participation in decision making is of outmost importance. In order to do so we have to enhance public's legal consciousness [42].

Preventive measures for the protection of public health during the reign of Venice, as discussed above, were directly correlated with the information available. The networks of information involved local society as well as officials and they all took part in the functioning of the lazarreti. Of utmost importance was the co-awareness regarding the uncertainty of the outcome of this crisis. Networks of information operated something like a living organism and practices and measures were under constant revision. On the other hand, the structure and functioning of lazzaretti, where local community were involved, enhanced local's people feeling of stability and safety needed in order to cope with the invisible enemy, the virus, and continue their every-day life.

\section{Rebuilding Politics of Cosmos}

We have to learn again how to record, store, report, collect and transmit information. Access to existing knowledge, [43] to past experience, skills and information are very crucial. It is of great importance to separate those aspects of the crisis that are inevitable and beyond our control from those that could be mitigated by thoughtful preparation. The misinformation at the start of the pandemic crisis and the constant lack of clarity and decision making by the WHO, made us question whether the current communication and warning tools, that international institutions like the WHO uses, ought to be replaced by other practices, where the networks of local people or participants, are predominant. The creation and establishment of independent international or rather transnational networks of businesses, professionals and citizens "the population at large", must actively be 
involved with the WHO. An information and visible network of professional doctors who will relay and communicate strategy, information and disseminate with clarity right from the start - and report directly back to local state councils, and local medical authorities. Medical bodies and authorities can in turn play an active role via the day-to-day involvement of health professionals, as well as a joint body of scientific experts from different disciplines, including the human and social sciences.

We are all residents of the same planet, and we are sharing the same boat. The ruling classes and citizens of the developed corner of the earth have no more rights than those that the indigenous and all the rest of our fellow human beings have. In this crucial crossroads or waypoint, what matters is not whether some of us are for or against globalization, but what really counts is understanding whether we are managing to register, to maintain and to cherish a maximum number of alternative ways of belonging to the world [43]. The notion of solidarity and collective action against the same enemy: the virus. The consistency of the transmitted message and the involvement of the local community to decision making becomes a necessity. Communicating the uncertainty is of outmost importance [44].

Thus the recommendation of the French National Consultative ethics committee regarding the ethical issues in the face of the pandemic for all actors, encourage action and promote amongst other things, transparent and accountable communication based more on society and based more upon the actual and active involvement of the population at large, of people. In a period when constraints weighing on individuals will be necessary from a health point of view it is essential not to worsen the health crisis by generating or widening the crisis of trust in society. It is recommended the setting up of a joint body of scientific experts from different disciplines, including the human and social sciences in conjunction with members of civil society. Collective and just solution and international solidarity, is a necessity in the fight against the spread of the disease. It is clear that global domestic politics prevails when our most mundane problems become global but the institutionalized answers remain national and need the involvement of the local citizens.

\section{References}

[1] Nicoll, A \& V. Murray, (2002) Health protection: a strategy and a national strategy. Public Health 2002; 116 (£): 129-37.

[2] WHO (2020) Coronovirus Disease. Pandemic. Retrieved 20 December 2020 from: https://www.who.int/csr/resources/publications/introduction/e $\mathrm{n} / \mathrm{index} 5 . \mathrm{html}$.

[3] Beck, U. (2012) Twenty Observations on aword in turmoil, polity, 2012, p. 75.

[4] World Health Organization (20.1.2020). Novel Corona virus Situation Report. Retrieved 20 December 2020 from: https://www.who.int/docs/default- source/coronaviruse/situation-reports/20200121-sitrep-12019-ncov.pdf?sfvrsn=20a99c10_4.

[5] World Health Organization (30.1.2020). Statement on the second meeting of the International Health Regulations (2005) Emergency Committee regarding the outbreak of novel corona virus (2019-nCoV). Retrieved 20 December 2020 from: https://www.who.int/news-room/ detail/30-01-2020-statementon-the-second-meeting-of-the-internationalhealth-regulations(2005)-emergency-committee-regarding-the-outbreakofnovel-coronavirus-(2019-ncov.

[6] New York Times (2020). China Grapples with mystery pneumonia like illness. Retrieved 20 December 2020 from: https://www.nytimes.com/2020/01/06/world/asia/chinaSARS-pneumonialike.html.

[7] Columbia Journalism Review (2020). The pandemic and the information network. Retrieved 20 December 2020 from: https://www.cjr.org/analysis/covid-19-coronavirusuncertainty.php.

[8] Zacher, Mark W \& Tania J. Keefe.(2008) The Politics of Global Health Governance: United by Contagion (New York: Palgrave McMillan, 2008) p. 26.

[9] Caduff, C. (2020) What went wrong: Corona and the life after the full stop, MEDICAL ANTHROPOLOGY QUARTERLY, Vol. 0, Issue 0, pp. 1-21, ISSN 0745-5194, online ISSN 15481387. (C) 2020 The Authors. Medical Anthropology Quarterly published by Wiley Periodicals LLC on behalf of American Anthropological Association. All rights reserved. DOI: 10.1111/maq.12599, P. 7.

[10] Covello, V. T et al (2001), Risk Communication the West Nile Virus Epidemic and Bioterrorism: Responding to the communication challenges posed by the intentional or unintentional release of a pathogen in an urban setting, J Urban Health, 2001; 78 (2) p. 382-91.

[11] Slovic, P. (1999) Trust, Emotion, sex, politics and Science surveying the risk assessment battlefield. Risk Annal. 1999; 19 (4): p. 689-701.

[12] Peters, R., Covello, V., McCallum D. (1997) The Determinants of trust and credibility in environmental risk communication: an empirical study. Risk Anal. 1997; (17) 1 p. 43-54.

[13] Renn, O. \& D. Levinne (1991) Credibility and trust in risk communication. In: Kasperson, R, Stallen p, editors. Communicating risk to the public. Dordrecht, Netherlands: Kluwer; 1991. p. 175-218.

[14] Santos, S., Covello, V., McCallum, D. (1996) Industry Response to SARA title III: Pollution prevention, risk reduction and risk communication. Risk Anal 1996; 16 (1): p. $57-65$.

[15] Abraham, T.(2009), Risk and outbreak communications: Lessons from alternate paradigms, B, World Health Organization, 2009; 87 (8) (2): 1-2.

[16] Abraham, T. (2011) Lessons from the Pandemics: the need for new tools for risk and outbreak communication Emerging Health Threats Journal, 4: 1, 7160, DOI: 10.3402/EHTJ.V4i0.7160.

[17] Covello, V. T. (2010), H1N1 risk and crisis communication: successes and challenges. Atlanta GA: Centers for Disease control and Prevention; 2010. 
[18] Covello, V. T. \& P. M. Sandman (2001) Risk communication: evolution and revolution In: Wolbarst A, editor. Solutions to an environment in peril. Baltimore: John Hopkins University Press; 2001, p. 164-78.

[19] International Covenant on Civil and Political Rights, Article 19.

http://www.ohchr.org/en/proffessionalinterest/pages/ccpr.aspx.

[20] OHCR, Committee on Economic, Social and Cultural Rights general comment no 14: The right to the highest attainable standard of health, 11 August 2000, http://www.refworld.org/pffid45388388D0.PDF.

[21] Art. 5 (1). UNECE (2014), The Aarhus Convention. An implementation guide, 2th edition, June 2014, Retrieved 10 May 2020 from: http://www.unece.org/env/pp/implementatin_guide.html.

[22] Nielsen, A., P., Lassen, J., \& P. Sandøe (2004). Involving the Public-Participatory Methods and Democratic Ideals. Global Bioethics, 17 (1), p. 191-201.

[23] UN (2020) We are all in this together. Human Rights and COVID-19 Response and Recovery, 23 April 2020, Retrieved 20 December 2020 from: https://www.un.org/en/uncoronovirus-communications-team/we-are-all-togetherhuman-rights-and-COVID-19-response-and.

[24] Council of Europe. Respecting Democracy, rule of Law and Human Rights in the framework of the COVID-19 sanitary crisis. A toolkit for member States, Information Documents SG/Inf (2020) 11, 7 April 2020.

[25] WHO (2020) Risk communication and Community Engagement (RCCE) Action Plan Guidance COVID-19: Prepardness and response, 16 March 2020, Retrieved 20 December 2020 from: http://www.who.int/publicationsdetail/risk-communicationand-community-engagement(rcce)-action -plan-guidance.

[26] Wynne, B. (1992). Public understanding of science research: new horizons or hall of mirrors? Public Understanding of Science, 1, p. 37-44.

[27] Sullivan, R. \& C. Kalipso. (2020), Urgent Call for an Exit Plan: The Economic and Social Consequences of Response to COVID-19 Pandemic. Centre for Global Development website, March 31. Retrieved 12 April 2020 from: https://www.cgdev.org/blog/urgent-call-exit-planeconomicand-social-consequences-responses-covid-19-pandemic.

[28] WHO, (2005) WHO outbreak communications guidelines. Geneva: World Health Organization; 2005 the other is and the US Centers for Disease Control and Prevention Crisis and Emergency Risk Communication guidelines and training module WHO Constitution, pp. 2-3.

[29] WHO (2016) Risk Communication. Pandemic influenza risk communication: Delivering Results in 2016 Retrieved 20 December 2020 from: https://www.who.int/riskcommunication/pandemic-influenza-preparedness/deliveringresults-2016/en/.
[30] Busby, J, What international Relations tells us about Covid 19?,https://www.e-ir.info/2020/04/26/what-internationalrelations-tells-us-about-covid-19/.

[31] Aaltola, M.(2020) Covid19-A trigger for global transformation? Political distancing, Global decoupling, and growing distrust in Health Governance, Finnish Institute of International Affairs, March 2020, 113, working paper, ISBN 978-951-769-632-6 ISSN 2242-0444.

[32] Sturgis, P., \& N. Allum, (2004). Science in society: reevaluating the deficit model of public attitudes. Public understanding of science, 13 (1), 55-74.

[33] Aginam, O. (2002). International law and communicable diseases. Bulletin of the World Health Organization, 80, 946-951.

[34] Scott S, Duncan C (2004) Return of the Black Death. The world's greatest serial killer. New York: John Wiley \& Sons; 2004 [Google Scholar].

[35] Konstantinidou, K. et al,(2009) Venetian Rule and control of Plague Epidemics on the Ionian islands during $17^{\text {th }}$ and $18^{\text {th }}$ centuries, Emerg Infect Dis. 2009 Jan; 15 (1): 39-43., doi: 10.3201/eid1501.071545.

[36] Kelly, J. (2005) The great mortality, an intimate history of the black death, the most devastating plague of all time. New York: HarperCollins Publishers Inc.; 2005 [Google Scholar].

[37] Konstantinidou, K. (2007) The disaster creeps crawling... The plague epidemics of the Ionian Islands [in Greek]. Venice (Italy): Hellenic Institute of Byzantine and Post Byzantine Studies; 2007. p. 129, p. 55-203. [Google Scholar].

[38] Deaux, G. (1969) The black death 1347. New York: Weybright and Talley; 1969 [Google Scholar].

[39] Kostis, K. (1995) During the times of plague. Perspectives for the communities of the Greek peninsula, 14th-19th century [in Greek]. Heraklion (Greece): University of Crete Publications; 1995 [Google Scholar].

[40] Howard, J. (1789), An Account of the Principal Lazarettos in Europe with Various Papers Relative to the Plague: Together with Further Observations on Some Foreign Prisons and Hospitals; and Additional Remarks on the Present State of Those in Great Britain and Ireland, (Warrington: printed by William Eyres, and sold by T. Cadell, 1789), p. 34.

[41] Cotterrell, R. (1997) 'The concept of Legal Culture, in Nelken, D. Comparing Legal Cultures (Dartmouth).

[42] Sharma, M.(2020) COVID-19 (An International Trauma): A Brief Analysis on Research Trends, Impacts and Solutions, International Journal for research in Applied Sciences and Biotechnology, ISSN: 2349-8889 Volume-7, Issue-2 (March 2020) https://doi.org/10.31033/ijrasb.7.2.1.

[43] Latour, B. (2018), Climate Earth, Politics in a new climate regime, p. 15.

[44] Foster, K \& P. Huber (1999) Judging Science, Scientific Knowledge and the Federal Courts, MIT Press, Cambridge, $p$. 235-240. 